\title{
BIOCIDES AND MAMMALS
}

\section{by Ralph D. Morris, Brock University, St. Catharines, Ontario}

The most frequently used chlorinated hydrocarbon insecticides are aldrin, DDT, dieldrin, endrin, heptachlor and toxaphene. Although their effectiveness in the control of insect pests has contributed significantly to human health and to the quality and quantity of commercial food and other crops (Jukes, 1963), we now have serious reservations about the advisability of continued widespread and uncontrolled use of them. Rachel Carson (1962) was the first to present the results of research studies in such a way that the attention of the layman (and of many scientists) was directed to the serious disruption of the environment caused by indiscriminate use of "control" chemicals. Despite many rigorous objections and denunciations, none of her major contentions has since been disproven.

It is an unfortunate fact that insecticides do not remain at the site of their application. DDT, for example, has become a ubiquitous contaminant, stored in the body tissue of even the most geographically isolated animals (Sladen et al, 1966) and suspended on particles of soil in air and water around the globe (Abbott et al, 1965; Risebrough et al, 1968). Increased use of other chlorinated hydrocarbons will undoubtedly result in their distribution equalling that of DDT as all have essentially similar chemical and physical properties. As all are virtually insoluble in water but readily soluble in many organic solvents and in fatty acids, living organisms actively concentrate the chemicals in the lipid component of their body tissues. This means that when chlorinated hydrocarbons are introduced into an ecosystem for the control of insect pests they are selectively concentrated out of the physical components of the system, and into the "lipid pool" of the biological components (Rudd, 1964).

Chlorinated hydrocarbon insecticides are directly toxic to most animals because they block the synthesis or operation of enzymes necessary for the normal functioning of the nervous and muscular systems (O'Brien, 1967). This toxic interference is non-selective as it is not restricted solely to the "target" pest. Further, all these insecticides are indirectly lethal, particularly to vertebrates, by inducing the synthesis of other enzyme systems which disrupt the delicate balance of steroid hormone levels (Conney, 1967; Peakall, 1967). The ramifications of this action are most apparent in certain species of birds where the causes of the "thin-egg shell" phenomenon are now well established (Ratcliffe, 1967; Hickey and Anderson, 1968).

The essential point is that, owing to similarity in mechanism of action and in physical and chemical properties, all of the chlorinated hydrocarbon insecticides should more accurately be considered as BIOCIDES.

My concern here is to use evidence from field and laboratory studies to suggest ways in which chlorinated hydrocarbon biocides directly or indirectly disrupt the behaviour, reproduction and ecology of wild mammal populations. Reference is made to Hayes (1965) for a complete review of absorption, metabolism, storage, excretion and general physiology of these chemicals in mammals.

\section{Effects on Mammals}

When confined mammals are given daily doses of chlorinated hydrocarbon biocides in their food, much of the residue is stored in adipose tissue although some is metabolized or excreted. Under certain conditions of stress, such as cold or starvation, the stored residue may be released for circulation and subsequently lead to the death of the animal (Dale et al, 1962; Morris, 1968). Such direct cause of mortality is probably rare in wild populations, but there are more subtle ways in which the release of stored residue may affect the health of a population. Transfer through the mam- 
For sep/71 "The Blue Jay" (add to list in June/71 issue.)

\section{SUGGESTIONS FROM THE BLUE JAY BOOKSHOP}

Notes

(1) Order through The Blue Jay Bookshop, P. 0. Box 1121, Regina, Sask.;

(2) Sask. residents add 5\% E. \& H. Tax; we do not collect sales taxes for other authorities;

(3) All prices sub ject to change without notice;

(4) Terms: payment within 30 daj8 of recolpt of book, but we are glad to consider requests for special credit arrangements.

10\% discount from regular list price given all supporting and sustaining members; NO DISCOUNT on books bought at retall or short discount wholesale, on SPECIALLY PRICED BOOKS, on our Special Publications; nor on orders under $\$ 5$ because of heavg postage rates.

ORDER NOW FOR CHRISTMAS:

Publishors are under heavy pressure from october until nearly christ18. To ensure getting gift books in time it is wise to order in september. books that must be bought in the U. S. often take two months to arrive. To elp our members, we have brought in a good number of fine books from reprint louses and jobbers, and these are offered at special Prices.

LANNING A LONG TR IP?

With air fares down and promising to go lower, distant lands can now e reached by many without undue strain. When you have settled on a trip, n joy that country's natural history by reading up on your subject well beforeand. Our list offors some examplos - lot us belp jou collect a useful library.

\section{HEN THAT DAY OF RETIREUENT COMES}

For most of us rotirement means a curtalled income. Perhaps ossential ooks will then be out of reach. Have your personal library well stocked ofore then - establish your own personal library buying plan while you can.

\section{SPECIALTIES FOR CHRISTMAS}

ICROSCOPI LAB. FOR YOUR YOUNGSTERS - 11.00

This dendy precision microscope is just the thing to stimulate the nquiring minds of your sub-teeners (ages 6 to 10). It will open up whole new orlds for them. The instrument has siz powers of magnification from 100 to oox. Four-piece dissecting set, a few slides (prepared and blank), slide reparation materials included but the pen-light batteries for the light source re not included. \$11.00.

\section{HRISTIVAS CARDS}

Floral emblem and scene: Saskatchewan Lily, Alberta Rose, Manitoba rocus, or 1 each 12 provinces and territories - \$1.00 dozen (with envelopes).

BOHEMIAN WAXWING (Kodachrome by Cy. Hampson) - \$1.00 dozen.

NY TIME: Show you're one of us - car windshield and home window decals of the Soclety's crest - $35 \$$ esch, three for $\$ 1.00$. 


\section{$-2-$ \\ BIRD BOOKS}

B1rd Gulde Index Tabs (we regret prices have all increased!) For "Blrds of $\$ 1.25$ each North America" by Robbins et al, and Peterson's Field Guides to Western Birds, European B1rds and Texas Birds.

Fleld Gulde Jackets, made of heavy gauge transparent vinjl with sealed seams, they w1ll add jears to the life expectancy of your field $\$ 1.25$ each guides. Two sizes: standard - for any Peterson guide and the limp edition of "Birds of North America" (Robbins); large size: far "Birds of North America" clothbound.

ADRIAN, M.: THE AMERICAN PRAIRIE CHICKEN, \$4.50, juv, 6x9, 64 pp. Th1s carefully researched account follows a prairle hen through the events of her I1fe cycle--courtship, nesting, raising a brood. An appealing story.

ALDEN, P.: FINDING THE BIRDS IN WESTERN MEXICO, paper \$9.25. A fleld gulde to a spectacular variety of west Mexico bird life that leads you into exotic jungles, pine-rimmed canyons, to sandy beaches. Beautifully 1llustrated.

ARMSTRONG, E. A.: BIRD DISPLAY AND BEHAVIOUR, Dover reprint, \$2.95, 438 pp. Th1s is an introduction to the study of bird psychology, a standard authority on bird display which initiate specific responses from others of th species. We have a highly readable, universally aoclaimed study.

BARTON, R.: HOW TO WATCH BIRDS, \$1.60 hard (Bonanza reprint). The author is a nature column1st and is thoroughly familiar with the questions birders most often ask and he answers these questions in deta11. 170. pp.

BEEBE, C. W: THE BIRD: ITS FORM AND FUNCTION, \$3.25, $507 \mathrm{pp} ., 374$ 1Ilus., Dove1 reprint. A fine general introduction to the study of birds, including much data on avian physlology, with a chapter on palaeontology.

BENT, A. C.: LIFE HISTORIES OF NORTH AMERICAN BIRDS - note NEW PRICES of these indispensable clessics for bird students:

Diving BIrds $\$ 3.50$ Shore Blrds Part $2 \$ 3.50$

Gulls and Terns $\$ 3.50$

Petrels \& Pelicans $\$ 3.50$

wild Fowl Part $1 \$ 3.50$

w1ld Fowl Part $2 \$ 3.50$

Marsh B1rds 4.75

Shore Blrds Part $1 \$ 3.50$

Wagtalls, Shrikes, ete.

$\$ 3.50$

Gallinaceous B1rds $\$ 3.50$

B1rds of Prey Part $1 \$ 4.75$

Birds of Prey Part $2 \$ 4.75$

Wood peokers $\$ 3.50$

Cuokoos, Goatsuckers \&

Humn 1ngb 1rds $\$ 7.00$

Wood Warblers $\$ 7.00$

Blackb1rds, Orioles, $\$ 3.50$
Flycatchers, Larks Swallows $\$ 3.75$

Jays, Crows, Titm1ce $\$ 7.00$

Nuthatches, Wrens, Thrashers $\$ 3.50$ Thrushes, Kinglets eto. $\$ 3.50$

Cardinals, Grosbeaks, Buntings and other Fringililds, 3 rols, set $\$ 18.00$

BROWN, I.: FAGLSS, cloth, $\$ 5.35$. An authoritative, beautifully illustrated sumary of the behaviour of eagles throughout the world, including result: of the latest research.

BRUCE, D.: BIRD OF JOVE, $\$ 7.50$ oloth, 224 pp., 1llus. The Berkut eagle - bird of emperors, emblem of the Roman legions, the greatest hunter of 1ts kind The struggle to tame an individual of the golden eagle of the Near Bast is a dramatic story.

CANTWELL, R.: ALEXANDER WIISON - Natural1st and Ploneer, $\$ 2.69,9 \frac{1}{4}$ I $12 \frac{1}{4}$. W1th 20 superb reproductions including 8 in full colour, from the original

Alexander Wilson engravings. The first man to study the birds of America in their native forests, his paintings are remarkable for their fldelity.

CARRICK, W. H.: NEST BOXTS FOR BIRDS, paper 35 hints for nest boxes and relates the types of nest boxes described to a large range of species, as well as describing wildlife studies in enough detall to arouse the interest of a wide range of age groups. 
CARAS, R.: SOURCE OF THE THUNDER: The Blography of a California Condor, $\$ 7.25$, illus., 5i $x$. As recently as 150 jears ago thousands of Californía Condors soared from the lfississippl Valley to the Pacific, yet only 50 now remain. Ihis book is a sensitive, flctionalized but factual reconstruction of the condor's life history.

CHAPMAN, F. M.: HANDBOOK OF BIRDS OF EASTERN NORTH AMERICA, \$5.25 (DOver reprint). The orlginal fleld guide; it covers nearly 700 species in greater detall than usual. The Dover reprint has improved the format and adds a colour chart and map.

THE WARBLERS OF NORTH AMERICA, \$3.75, 1llus. by Louls Agassiz Fuertes and Bruce Horsfall. Contributions of 37 leading naturalists have made this study of 55 species and 19 sub-species invaluable. 1 summary of general characteristics, distribution, plumage, migration, songs, feeding and nesting habits of each warbier are followed by individual ilfe historles in full detall. Erery species lilustrated, male and female.

CRA IGHEAD, J. J. \& F. C.: HAWKS, OWLS AND WILDLIFE, \$4.45 paper (Dover reprint). In this study of the predatory beharior of hawks and owls, the Cralgheads present their findings after years of intensive fleld research. They conclude that predation is not a cruel and wasteful process, but is a natural blological control or regulator.

RRICKSHANK, A. D.: A POCKET GUIDE TO BIRDS, paper, 60\&. This is a reasonably complete, hardy bird guide, excellent as a giveaway to friends and children who come into contact with b1rds to spark interest.

I SCHAUENSEE, R. M.: BIRDS OF COLUMBIA, $11.00,443 \mathrm{pp} ., 20 \mathrm{pls} .112$ in color), 87 flgs., 2 maps. The only handbook arallable in the English language for the birds of this unusually rieh region. In all 2,640 species are listed and their more obrious differences noted; 344 species illustrated.

$\triangle$ GUIDE TO THE BIRDS OF SOUTH AMERICA, \$21.00, $486 \mathrm{pp} .$, 50 plates (3l in color), 21 f1gs, 1970, cloth. Presents a rast amount of information in a brief and readily accessible form. The 2924 species inhabiting South America are deseribed, and the 1liustrations deplet more then 600 of the 865 genera found there.

UNNING, J. S.: PORTRAITS OF TROPICAL BIRDS, \$21.00, 4 to s1ze, 154 pp., 76 colored plates, 1970, cloth. A striking colleotion of color photos depicting tropical birds in brilliant plumage.

ASTMAN, W. R. \& HUNT, A. C.: PARROTS OF AUSTRALIA, \$13.50, 192 pp., 28 color plates, $16 \mathrm{pp}$. b.w. illus. Th1s guide to fleld 1dentification and babits of Australian parrots describes and 1llustrates a group of beaut1ful b1rds. Magnificent color work includes paintings and kodachrome spreads.

LIIS, M.: THE WORID OF BIRDS, $\$ 6.95$ SPECIAL PRICE (Or1g. \$10.00). Th1s largo

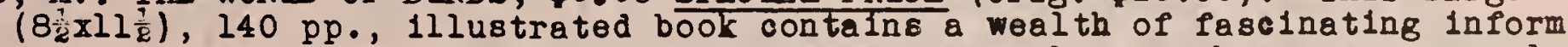
ation. Every page contains photographs, elther colour or b. W. An unusual feature is a chapter on bird artists and thelr work (1ncluding Lansdowne).

ARNER, D. S. \& KING, J. R.: AVIAN BIOLOGY, Vol. 1, \$32.00. Th1s mult1rolume treatise is a comprehensive survey - written by international authorities of the established facts and principles of arian biology. In particular, it reviews in detall a great amount of new information on the 8,600 iring species of birds. Vol. I is concerned primar1ly with systematics, population blology, and ecology. Many other topics are discussed.

CRSHAW, J. M.: AUSTRALIAN PARROTS $\$ 31.00$, fol10 $8120,320 \mathrm{pp}, 77 \mathrm{pp}$. color paintings and photos. A new study of these respendent birds, ranging from the Port Lincoln Parrot to the Budgerigar.

ABRIRLSON, I. N. \& JEWETT, S. G.: BIRDS OF THE PACIFIC NORTHWEST WITH SPECIAL REFERENCE TO OREGON, \$5.75, paper, 680 pp., 97 pls. Dover reprint. 'lhis is an unaltered republication of the Birds of oregon, 1940. It applies to the broad area of the Pacific Northwest with its rich avifauna. 
$-4-$

GODFRIY, W. E.: BIRDS OF THE CYPRESS HILLS AND FLOTTEN LAKE REGIONS, SASK. 35 paper, 96 pp., 4 pl., 2 maps. Descriptions of the blrds and country they inbabit as seen during the National Museum's expeditions of 1948.

(BIRDS OF CANADL) out of print but being reprinted. New price will be 15.00 it 18 understood.

GOODERS, J.: WHERE TO WATCH BIRDS IN EUROPI, \$6.75, $293 \mathrm{pp} ., 111 \mathrm{us.} \mathrm{Th18} \mathrm{bo0k}$ gires detalls of the best bird-watching areas in 27 countries (Andorra and Leichtenstein not incl.) with dete of routes, access, local societies, etc as well as the pecies to be expected at different seasons; many maps. An indispensable companion on that trip. A book to treasure and dream orer GROME, 0 . J.: BIRDS OF WISCONSIN, $27.75,236 \mathrm{pp}$, 11lus. with 105 full color plates of 328 spec18s.

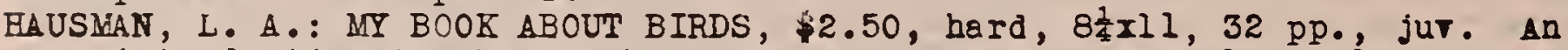
introduetion to the songbirds of America, with detailed ilius. in color. Even the smallest child can learn to recognize birds using this book.

HA VERSCHMIDT, F.: BIRDS OF SUR INAM, $\$ 39.25,500 \mathrm{pp} ., 60 \mathrm{pls.}$ (40 in color) 150 text 1lius. The first complete book on the ornithology of Surinam, or Dutch Guiana. With colored plates 1llustrating 537 species.

HEADSTROM, R.: A COMPLETE FIELD GUIDE TO NESTS IN THE UNITED STATES, \$1I.00. Includes nests of birds, mamals, insects, fishes, reptiles sc amphibians. 493 pp., 49 photos, 1970 , cloth.

photos. BIRDS' NESTS, A FIELD GUIDI, \$5.25, hard cover. $128 \mathrm{pp} ., 61$

BIRDS' NESTS OF THE WEST, $\$ 4.75$, cloth, 177 pp., 29 photos. Companion books covering nests of more than 300 birds of each reglon; the west is the region from the Cordiliera to the Pacific. They contain quiek unique keys for the ldentification of any nest by 1 ts location and structure.

HICKFY, J. J.: PEREGRINE FALCON POPULATIONS, THEIR BIOLOGY AND DECIINE, \$13.50, cloth. Once the prized farourite of medieral falconers, this study attempts to establish the cause of the decline of peregrine and bird populations everywhere.

HILI, R.: AUSTRALIAN BIRDS, \$18.95, 4 to size, 281 pp., 300 color pls. A larisk book, with all birds illustrated in color. Describes 700 secies and includes classification and check-11sts. SPECIAL PRICE (Or $1 \mathrm{~g} . \$ 36.00)$

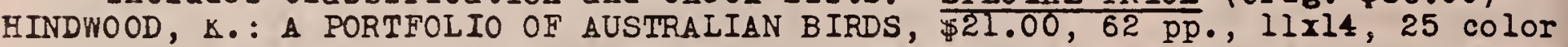
pls. by W. T. Cooper. Here, with an imaginative precision that no camera could emulate, the artist has captured the special character and backcround of 25 of Australia's more interesting and beautiful birds. A page of Iively, comprehensire and informative text accompanies each iliustration

HOUSTON, $\mathcal{C}$. STUART \& STREFT, M.: THE BIRDS OF THE SASKATCHEWAN HIVER, CARLETON TO CUMBERLAND, $\$ 1.50$, paper. (SNHS Spec. rub. \#2). This is a finely annotated list of 259 species, with excellent historical researeh.

IVOR, H. R.: 1 LIVE WITH BIR9S, \$6.95. "Th1s must be one of the most enjoyable books to come along this year - or any year." (Hamilton Spectator). "Th18 enchanting book w1l be a constant pleasure and reference for all those who are fortunate enough to have it as part of their nature librarj." (Robert $r$. Gunn, Naturalist Review)

JOHNSGARD, P. A.: HANDBOOK OF NATERFOWL BEHAVIOR, \$13.75, 392 pp., 20 photos., 95 drawings. The behavior patterns of ducks, geese and swans, 11lus. basie postures and movements and comparing beharioral variations with difference in anatomy, ecology, and evolutionary relationships.

WATHRFO'WL: THEIR BIOLOGY AND NATURAL HISTORY, $\$ 10.50,375 \mathrm{pp}$ 150 photos (59 color). Hritten for the layman as well as the biologist, it covers distribution, migration, ecology, food, behavior, plumages and other subjects:

KORTRIGHT, F. H.: DUCKS, GEESE AND SWANS OF NORTH ANERICA, \$9.50 cloth, 484 pp. 36 col. pls. by T.M. Shortt; $11 \mathrm{gs.,} \mathrm{maps.} \mathrm{Perhaps} \mathrm{the} \mathrm{most} \mathrm{important} \mathrm{hand}$ book on waterfowl erer published. A unique reference book; a joy to read. 
LAND, H. C.: BIRDS OF GUATEMALA, \$11.00, 300 pp., 44 pp. In color \& b.w. Intended for field use.

LANSDOWNE, J. F. \& LIVINGSTON;, J. A.: BIRDS OF THE EASTERN FOREST VOI. I \$20.00 BIRDS OF THE EASTERN FOREST VOI. 2 \$2.50; BIRDS OF THE NORTHERN FOREST 20.00. Both author and art1st are justly famous throughout the Englishspeaking world for these magnificent folio rolumes with paintings of birds by Lansdowne, accompanied by a pege of descriptive text by John Iivingston.

LONGRIDGE, J.: CHINESE BIRD PAINTINGS, $\$ 13.50$, 1IIus. The besis of th1s selection of plates is an album of bird paintings produced during the ching Dynasty and the latter half of the Ch'ien Lung perlod (1736-1796), and commissioned by a member of the Imperlal Household from an unknown artist. MATHEWS, F. S.: FIELD BOOK OF WILD BIRDS \& THEIR MUSIC, \$3.25 paper, DOver reprint., 369 pp., 71 pls. 127 specles covered, with musical scores.

MATHEWSON, R.: BIRDS - \& HOW AND WHY WONDER BOOK, $59 \phi$, peper, jur. The \&uthor is Curator of Science, Staten Island Institute of Arts and Sciences. It is almost unbelievable, the wealth of factual information which has been introduced into the 48 profusely lilustrated 8 i $x 11 \mathrm{pp}$. in thls book.

ILNE, L. \& M.: NORTH AMERICAN BIRDS, $\$ 29.95,384$ pp. 9xl2, illus. This magnificent volume contains beauty, sensitirity, and scientific accuracy. A definltive study of the most popular of all animal subjects, birds, it covers the complete range of species found on this continent.

IELSON, B.: GALAPAGOS: ISILANDS OF BIRDS, (SPECIAL PRICE \$5.25 - Or $18 . \$ 7.95$ ). 333 pp., profusely illus. With photos and drawings, foreword by E.R.H. The Prince Phllip, Duke of Edinburgh. This book combines serious nature study with readable prose. Bryan Nelson and his wife spent a jear on the Galapagos. He describes their months of isolation in lively text.

NRRO, R. W.: BIRDS OF THE LAKE ATHABASCA REGION, SASKATCHEWAN, \$2.50 paper. BIRDS OF NORTHEASTERN SASKATCHEWAN, pQper 2.00.

These special publications of the S. N. H. S. are among the best annotated bird lists avaliable of any region. Fine fleld work in remote regions.

ICE, M. M.: THE WATCHER AT THE NEST, 1.80 , Dorer reprint, paper. A populer, genial and charming account of research carried out in the highest traditions of sclence - the story of two song sparrows observed during eight years of intensive study. "A monument to the patience and persistence of a keen observor and careful historlan." ("Natural History")

ALIER, W.: LIVING SCIENCE - BIRDS, \$2.95, hard cover. Today the emphasis on sclence begins at an early age, and here the author succeeds in making the study of birds an exciting and interesting experience for youngsters from age 6 to 9 in his presentation of facts covering many species from the humingbird to the ostrich. Illustrations on each of the $60 \mathrm{pp}$.

ARKER, B. M.: THE NEW GOLDEN TREiSURY OF NATURAL HISTORY, cloth \$5.95. YOu could hardiy give a youngster a better gift:

ARKKRR, J. \& P.: ORNAMENTAL WATERFOWL AND OTHER EXOTIC GARDEN BIRDS, \$8.50. Here is an ideal introduction to a fascinating hobby. With a fair-sized area of land near home and the interest, one can have a backyard full of exotic birds. Acturily, this is a paying proposition in many cases.

PETERSON, R. T.: A FIELD GUIDH TO THE BIRDS OF BRITA IN AND EUROPE, \$8.75; When you take that European trip, you must have this book along, as weIl as

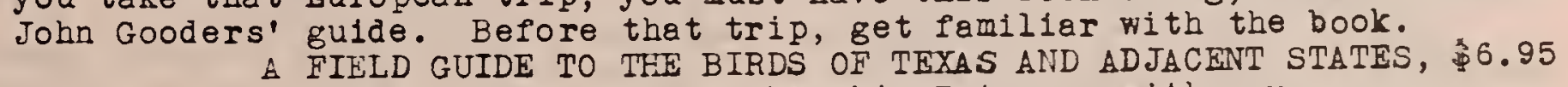
If you head south for the winter, take this Peterson with you.

A HIELD GUIDE TO WESTERN BIRDS, $\$ 6.95 . \cdot . \cdot$ and if you stay at home, this is still the most use ful ldentifier to hare on hand. ALL THREE can be made more useful with Index Tabs and plastic jackets. 
$-6-$

PETERSON, R. T.: HOW TO KNOW THE BIRDS, 95\& peper. This is a handy, well-illus. trated guide to the birds. The expert shows how to make bird-identificetion quick and accurate by noting key markings, silhouettes and flying styles, as well as habits and peculiarities.

PETERSON, R. T. \& FISHER, J.: THE WORID OF BIRDS - SPECIAL PRICE \$7.95 (Orig. \$27.95) Reprinted by the Bonanza people; a magnificently iliustrated general work which analyzes the blology and way of life of the entire galaxy of birds known to exist. (Not to be confused with Ellis's book!)

POOIE, E. L.: PENNSYLVANIA BIRDS: AN ANNOTATED IIST, cloth, \$5.00. 103 pp., 74 drawings, 34 maps.

PETTINGILL, 0. S.: ORNITHOIOGY IN LABORATORY AND FIELD, $\$ 12.50,4$ th $\theta$ d. 4 to size, $542 \mathrm{pp}$., $30 \mathrm{pls}$. This work incorporates the more important recent advances in knowledge of avian ecology, speciation, migration, physiology, and breeding biology. An important source book for any level of student.

RAND, A. I.: ORNITHOLOGI, AN INTRODUCTION, paper \$1.50. This comprehensive survey of the biology of birds emphesizes the evolutionary aspects that have given birds their dominant place in nature. Excellent arian science.

REED, C.: NORTH AMERICAN BIRDS EGGS, paper $\$ 4.10$. This is the comprehensive work on this subject. Thoroughly revised by Cornell, with all material brought up to date in accordance with the AOU 1957 Checklist. Dover reprint.

ROY, J. F.: BIRDS OF THE ELBOW, mimeo 75中. This is a publication of S.N.H.S. describing in a preliminary way the birds of the elbow of the saskatchewan River, much of which is now flooded by Lake Diefenbaker.

SANGER, M. B.: CHECKERBACK'S JOURNEY: THE IMIGRATION OF TEE RUDDY TURNSTONE, $\$ 4.95,7 \frac{1}{4} \times 10 \frac{1}{4}, 150 \mathrm{pp}$., many drawings. Checkerback is a Ruddy Turnstone migrating from Brazil up the coast of North America to Greenland. Hollowing his flight, the author tells the fascinating story of the ecology of the entire Atlent1c seacoast, discussing birds and other wild creatures.

SAUNDERS, A. A.: AN INTRODUCTION TO BIRD LIFE FOR BIRD WATUHERS, $\$ 1.50$, paper, Dorer reprint, $250 \mathrm{pp}$., illus. With drawings. Fere is a fine, readable introduction to birdwatching, giving the reader much basic information about 160 species. It can be used before adrancing to specialized books.

SCHUTZ, W. F.: HOW TO ATTRACT, HOUSE AND FEED BIRDS, \$9.50. An enlarged edition of "Bird Watching, Housing and Feeding". A complete handbook for those with an interest in birds, including ecology, conservation, etc.

"SCIENTIFIC ANERICAN" Readings in the Life Sciences - each 45 : "The Phalarope" by E. O. Hohn. "How Birds Sing" by C. H. Greenewalt. "Darwin's Finches" by David Lack.

"Erolution of Bowerbirds" by E. T. Gilliard. "Visual Isolation in Gulls" by $N$. G. Smith.

"The Erolution of Behavior in Gulls" by N. Tinbergen.

"Celestial Navigation by Birds" by E. G. F. Sauer.

"The Language of Birds" by W. H. Thorpe.

SMITI, N. G.: THE EVOLUTION OF SOME ARCTIC GULLS (LARUS): An Experiuental Study of Isoleting Mechanisms, paper, $\$ 3.35$

SPARKS, John: BIRD BEKAVIOUR, \$4.95. 'lhe private world of birds and the intricacies of bird behaviour - feeding, courtship, nesting, etc. The complex social relationships of flocking blrds are described.

SPRUNT, A. \& ZM, H. S.: GAMEBIRDS - A "Golden Nature" Guide to North American Species and Their Habits, paper, $\$ 1.50$. Includes a note on the 34 species unsuccessfuliy introduced.

STEVENSON, G. B.: BIRDS, a quiz-me book, paper, 594. A small (4x6., 48 pp.) colourful item for youngsters, full of fascinating data, ending with a qui:

STOKES, T.: BIRDS OF THE ATLANTIC OCEAN, \$8.50 SPECIAL PRICE (Or $1 \varepsilon . \$ 14.50)$ This magnificent book, $9 \frac{7}{2} x 12$, offers the most complete collection of ocean bird illustrations ever published. In a lively and authoritative text the author alsousees at length each individual species in full detail. 
ARLAND, $N_{*}:$ A TERRITORY OF BIRDS, 2.75, cloth, 232 pp., many b.w. photos. The author spent two years in Australia's Northern Territory, culminating in a search for the near-extinct Night Parrot. We get a striking picture
of the country and the people who live there. SPEC. PRICE $\$ 2.75$ (was $\$ 4.75$ )

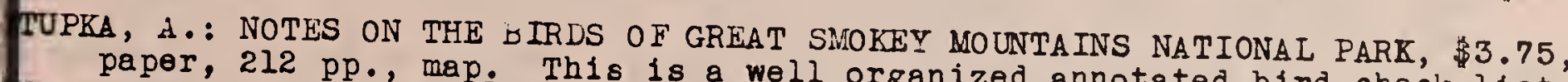
paper, 212 pp., map. Th1s is a well organized annotated bird check-list.

KNONS, R. D.: HOURS AND THE BIRDS, 12.50 , cloth, $256 \mathrm{pp}$, 16 colour plates. In this book the author reveals his intimate knowledge of the habits, tho subjects of his own and beauty of prairie birds, many of which are the subjects of his own paintings illustrating this outstanding volume. ERRES, J. K.: SONGBIRDS IN YOUR GARDEN, $\$ 7.25,256 \mathrm{pp} ., 7 \times 9 \mathrm{q}$. A delightful, fact-filled book by the editor of sudubon Magazine. How to enrich jour life by attracting birds. A sensitive text, well illustrated.

OMAS, A.: BIRD AMBULANCE, \$8.75. Living in a suburb of New York, Mrs. Thomas made friends with a wild bird thet came to her feeder and when it was injured nursed it back to health. This led to work with the bird-saring corps of the Audubon Society. A charming, humerous book.

AN TYNE, J. \& BERGER, A.: FUNDAMENTALS OF ORNITHOLOGY, \$4.00, paper (Dover). Contains complete treatment of the breeding biology of birds, presents a critical summary of plumages, and provides a modern review of the theories of bird behavior, song, migration, feeding habits, etc.

EENS, JOHN A.: AN APPROACH TO THE STUDY OF ECOLOGICAL RELATIONSHIPS AMONG GRASSLAND BIRDS, paper, \$3.35. Nieadowlarks and grass sparrows were studied on an 80-acre prairie at Madison, wisc., to develop and test a mothod for describing and analyzing habltats which would be useful in elucidating ocological relationships among grassland birds.

M, H. S. \& GABRIELSON, 1. N.: BIRDS - A "Golden Nature" Guide to the most Familiar American Birds, paper, $\$ 1.50$, picturiag 129 birds in full colour.

\section{PLANT AND TREE BOOKS}

STT, K. H.: \& BUDD, A. C.: COMWON WEEDS OF THE CANADIAN PRAIRIES, paper, \$1.00. Some 180 plants are included and each one has a written description and a simple line drawing. Whe key will aid in identifying plants while small.

$A K E$, S. F. \& $\triangle T$ TWOD, A. C.: GEOGRAFHICAL GUIDE TO THE FLORAS OF THE WORLD, Part l (Africa, Australia, N. America, S. America, and Islands of tho Atlantic, Pacific and Indian uceans), \$7.00,336 pp., 1942 (reprint). No list of the scope of this one has ever been published. Its a im is to furnish an annoted catalog of all the now useful floras and floristic works, including those in periodical literature, that list or describe the complete vascular flora (or the phanerogams only) of any region or locality DNNER, J. \& GALSTON, A. H.: PRINCIPLES OF PLANT PHYSIOLOGY, $8.25,499$ Pp., 219 lilus., 1952. The authors have written a text which will be useful to students in the applied fields of botany as well as those interested in plant physlology itself. ("The American Naturalist")

RACKMAN, ZIM, et al: TREES OF NORTH AMERICA - A Guide to Field Identification. $11 \mathrm{mp} \$ 4.50$, cloth $\$ 6.95$. Like its companion BIRDS OF NORTH AMERICA, this book is fully illustrated in colour. An excellent identification aid.

RMICHAEL, L. T.: COMON MARSH PLANTS OF SASKATCHEWAN, paper, 35\&. \& Saskatchewan Museum publication, illustrated with b.w. drawings.

PRA IRIE NILDFLOWERS, cloth, $\$ 3.00$. This is the most suitable first reference for prairle dwellers. Not technical, but accurate. Illus. SASKATCHEWAN WILDFLOWERS: WESTLRN AREA, paper, 80ф. Another Saskatchewan Museum publication, 1llus. with b.w. drawings. WOODLAND WILDFLOWERS OF EASTERN SASKATCHEVAN, pa per, $50 \%$ This SINH publication completes a spread of guides for wildflowers made specially for this country. 
DORE, W. G.: WILD RICE, paper, 2.00. The only cereal crop that grows wild in Cangda, wild rice factual information was surprisingly sparse until this small volume appeared. It gives its botany, distribution, habitat, etc.

FLOCK, E. B.: WILD FLOWERS OF THE PRAIRIES, 85 $\phi$, paper. The description of each flower is given alphabetically under its common name. A sketch of each is included to aid in recognition.

HARP, H. F.: THE PRAIRIE GARDENER, \$8.95, cloth. The CBC's Prairie Gardener has given us a comprehensive discussion of all aspects of the prairie gar den. Mr. Harp, a professional, has spent 40 years on the prairies growin things and contributing to the study and development of hardy plants.

HOSIE, R. C.: NATIVE THLES OF CANADA, paper $\$ 5.00$, cloth $\$ 8.00$. Th1s is an excellent reference on our native trees. The photos are clear and the descriptions well organized. We who make do with the older editions can see immediately the great advance this new edition has made. The added appendices themselves are worth the increase in price.

HUI-LIN LI: WOODY FLORA OF TAIWAN, $\$ 20.00,974 \mathrm{pp} ., 371$ 1lius, 6x9. A complet flora of the woody plants of Taiwan, with descriptions of 105 families, notes on distribution, uses, and habitats, with useful keys.

MIINE, L. \& M.: LIVING PLANTS OF THE WORLD, \$11.95 SPECIAL PRICE (Was \$17.95.) 340 1llus. 176 in full color. Magnificent presentation of 150 species serving man as adornment, food, medicine, narcotics, etc. and history.

NATIVE PIANTS OF FENNSYLVANIA: A TRAIL GUIDE TO THE BONVAN'S HILL STATE WILD FLOWER PRESERVE, \$2.00, paper. A useful pocket guide to the native plant of the middle Atlantic region; 100 illus., some color, blooming date inde:

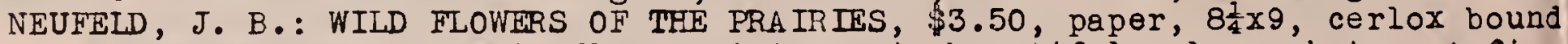
This is an album of 28 flower pictures in beautiful colour photos. A Ine gift, and an excellent means to teach children flower recognition.

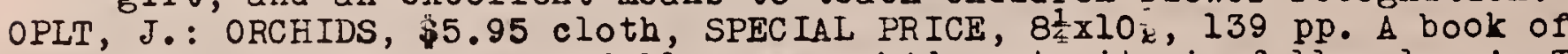
incredible beauty, 56 full-page orchid portraits in full colour! The fir chapter gives the basic principles of orchid growing. Nore detailed data is given opposite each plate; 149 species described from 39 genera.

POPE, W. T.: MANUAL OF THE WAYSIDE PLANTS OF HAWAII, $\$ 7.25,296$ pp., 160 plate bibliog., cloth. The flora of Hawail is particularly interesting because it largeiy consists of plants introduced from other parts of the world.

RICKETT, H. W.: WIID FLOWERS OF AMERICA, \$8.95 SPECIAL FRICE, was \$̋18.75. 400 flowers in full color, palnted by Mary Vaux Walcott, with others by Doroth platt. Detailed descriptions and full data on family, range, etc.

SEYMOUR, F. C.: THE FLORA OF NEW ENGLAND, $15.00,612$ pp. $7 \times 10,390$ photos, cloth, glossary. This is the only comprehensive book on the flora of New England.

\section{OTHER NATURAL HISTORY (incl. books on INDIANS)}

ABBOTT, ZIM \& SANDSTROM: SEASHELLS OF NORTH AMERICA, I1mp \$4.50, cloth \$6.95. A fact-filled book on seashells for all those spending time at the coast. ABBOTT \& ZIM: SEASHELLS OF THE WORLD: A GUIDE TO BETTER KNOWN SPECIES, paper, \$1.50. A "Golden Neture" Guide giving a good picture of this study.

ADAMS, C. V. A.: COLLECTING FROM NATURE, 3.95 , juv., 250 pp., 11lus. A book for young people who want to know how to begin collecting, preserving and mounting specimens - butterflies, beetles, fungi, etc, for display.

ALIEN, G. [1.: BATS, $4.00,378$ pp., 58 1llus. vover reprint. Considered one o: the most comprehensive works on Bats ever published.

ANDREWS, R. C.: NATURE'S NAYS: HOW NATURE I'AKES CARE OF IIS OWN, \$6.49 BONANZA

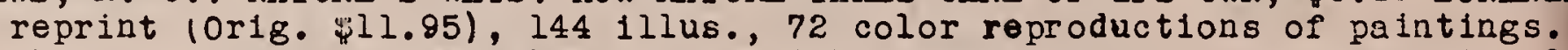
The etrange and wonderful ways in which Nature's creatures have equipped themselves for survival. An exceptional book for all the family. 
VG IER , B. : WILDERNESS COOKERY, \$1.95. Mouth-watering campfire, on-the-trail ways to prepare fish, game, and side dishes to tempt even the kitchenbound. Unusual entrees and new treats but still a practicel book.

DA: LAND CAPABILITY FOR WILDLIHE - UNGULATES MAP WILLOW BUNCH LAKE 72H. $35 \%$

WATER, M.: AVALANCHE HUNTERS, $\$ 8.75$. The first book written about the avalanches of North America. With a foreword by Lowell Thomas.

IDUBON ANTMALS IN FULL COLOR, $\$ 8.95$ (Orig. Price $\$ 30.00$ ). A monumental volume from the famous Imperial Collection. 150 of Audubon's best animal paintings with anecdotal original text material included plus other information. ITHENTIC MUSIC OF THE AMER ICAN INDIAN, 3-record set $\$ 7.95$ (Orig. price $\$ 18.00$ ). Contains the music of over 20 western tribes (Sioux, Apeche, Hopi, etc.). War dances, honor songs, ceremonial songs and chants, social and folk songs

IRD, D. M.: NATURE'S HERITAGE - CANADA'S NATIONAL PARKS, \$9.95, 144 pp.9x12. A sumptuous book that brings together outstanding photos of some of venade's most breathtaking scenery. 36 color and $100 \mathrm{b.w.,}$ area maps, text.

RBEAU, M.: INDIAN DAYS ON THE WESTERN PRAIRIUS, paper $\$ 5.25,8 \times 10,234 \mathrm{pp}$. profusely illustrated b.w. Authentic history froy our National Museum.

RR, D.: PRIMITIVE MAN (a "How and Why Wonder Book") paper, 59ф. A comprehensive, easily-understood presentation of Man's journey through time. Juv.

EEBE, B. F.: AFRICAN APES, $\$ 4.75$, juv. In this book packed with information about african a pes, a popular husband-wife naturalist team provides a wealth of information about the personalities and characteristics of them.

CK, W. H.: A GUIDE TO SASKATCHEWAN MAMMALS, 50 $\phi$, paper. SNHS spec. Pub. \#1. Gives the occurrence details of every mammal recorded for the province.

TRAM, B.: DINOSAURS (a "Quiz-men book), paper 59ф. 48 pp., $4 \times 66^{\prime}$. Essential facte briefly but well told for youngsters, ending with a quiz.

EEKER, S.: INDIANS (a "Quiz-me" book), paper 59ф. Another in the series presenting solid information, ending with a knowledge test.

HLKE, J. E. \& CHAPLIN, C.C.G.: FISHES OF THE BAHAMAS, $\$ 30.50,880$ pp., illus. $7 \frac{1}{2} \times 10$. This is the first major scientific study of the fishes of the Caribbean waters in over 30 years; 32 col. pls. 700 drawings, 500 species.

REAL INSTITUTE, UNIV. OF ALBERTA: IMPLICATIONS OF NORTHERN MINERAL RESOURCES MANAGEMENT FOR HUMAN DEVELOPMENT, $\$ 2.00$. Report of a symposium.

NNER, J. T.: THE IDE'SS OF' BIOLOGY, peper, \$1.75. The book centralizes the ideas of biology around four of its parts, evolution, cells, genetics, development (of complex organisms). Very readable for laymen.

OWN, V.: AMATEUR NATURALIST'S HANDBOOK, cloth $\$ 2.69$ (SPECIAL, was \$5.95). 200 illus, $475 \mathrm{pp}$. Compact guide, describes rocks and minerals, how to collect plants, animals, weather forecasting, etc. etc. etc.

TGESS, T. W.: BURGESS BOOK OF NATURE LORE, \$2.69 (SPECIAL, was \$5.95), cloth, juv. 26 stories of how animals and plants make the most of life told in charming style with lots of real netural history.

THE CROOKED LITTLE PATH, \$2.00 (SPECIAL, was 4.75 ), cloth, juv. 26 delightful stories about the animal characters we all know, Peter Rabbit Buster Bear, Prickly Porky, Little Joe Otter, and others.

HALANE, V. H.: ALIVE IN THE WIID, $\$ 9.95,240 \mathrm{pp} .7 \times 9 \frac{3}{4}$. The marvelous, mysterious, richiy varied animal kingdom set out in a fascinating and informative book. The editors have combined pieces by outstanding zoologists.

ILLEUX, A.: ANATOMY OF THE EARTH, paper $\$ 3.00$, cloth $\$ 5.85$. A concise general introduction to geology. It examines the earth's external and internal leatures, its evolution, and its place in the universe as a wholo.

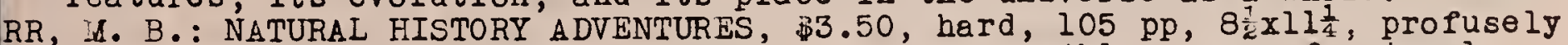
ilius. col. \& b.w. The book touches on an incredible array of natural history subjects. Meant for children, it would surely inform many adults.

RRIGHAR, S.: WILD HERITAGE, \$2.69 (SPECIAL, was $\mathbf{5}^{2.95}$ ). The animal world in action, a beautiful picture of animals leading their own lives. Much behavioural information. 
COHEN, D.: $\triangle$ MODERN LOOK AT MONSTERS, $\$ 7.25,256 \mathrm{pp} 6 \times 8 \frac{1}{2}$. The author uses the latest soientific information to examine the stories of monsters in the modern world, Loch Ness Monster, Abominable Snowman, living mammoths, etc WATCHERS IN THE WILD: THE NEW SCIENCE OF ETHOLOGY, $\$ 6.75,192 \mathrm{pp}$. $5 \frac{1}{2} \times 8$. The study of animals in their native habitats. The controversies induced by Lorenz, Ardrey, Morris are examined. A useful adult book.

COOK, F. R.: AMPHIBIANS AND REPTILES OF SASKATCHENAN, peper, $40 \notin$. From the Saskatchewan Museum of Natural History.

GRAIGHEAD, F. C. \& CRAIGHEAD, J. J.: HOW TO SURVIVE ON LAND AND SEA, \$5.75 pape A detailed text on human survival under all conditions and in any climate.

CURTIS, N.: THE INDIAN'S BOOK, $\$ 4.75$ (Dover reprint). A book created wholly by the North American Indian, with songs, myths, drawings and decorations based on traditional designs, deriving directly from tradition. The texts are written out in both the native language and English, melodies provided

DAY, M.: FOSSIL MAN, $\$ 4.95$. This all-color guide shows the physical evolution of our own species from early primate ancestors through ape men to Homo sapiens, traced in a clear and well documented style, using the latest dat

DAVIS, C.: NORTH AMERICAN INDIAN, \$5.95 (intro. by Marlon Brando). The fir st helf of the book outlines the fall of the Indians, the second half deals with their trials and problems today. Illus. with maps, prints, photos.

DITMARS, R. L.: STRANGE ANIMALS I HAVE KNOWN, 75\%, peper. A curator of New York's Bronx 200 for many years, the author describes his intimate adventures with the creatures destined for his zoo to create a fascinating story

ERRINGTON, P. I.: MUSKRAT POPULATIONS, \$10.50. This book was assembled over a 25-yr. period and represents 30,000 hours of field studies. A skilled and sensitive writer, his facts become highly interesting as well as informati OF MEN AND MARSHES, $\$ 5.50$. In this book of memories and philosophy, the author unvells the little known world of life in wetlands. OF PREDATION AND LIFE, $\$ 7.50$. As a presentation in popular form of the research on the phenomenon of predation, the book emphasizes the role of predation in biological systems. $277 \mathrm{pp}$., illus. $6 \times 9$, cloth. FRCOM, B.: SNAKES OF CANADA, 77.95 , 1llus. A useful identification guide and a descriptive discussion of the origin, classification, etc. of our snakes.

HAMPSON, C. G.: HAIRY FRIENDS, \$6.95. This book, with superb pho to s by the author, brings to us Dr. Cy Hampson's keen observational skill. in each chapter he recounts a sympathetic, personal involvement with an animal.

HELBEMAL, G. J.: A CFIPMUNK ON MY SHOULDER, $\$ 3.25$. An unusual and amusing book about the companionship between a men and his two quick-witted chipmunks.

HOLIAND, W. J.: THE MOTH BOOK, \$5.75 paper (DOver reprint). This is a great classic, and serves as a definitive reference work for collectors. Illus.

JONES, H.: THE TREES STAND SHINING: The Poetry of the North American Indians. $\$ 5.95$, illus. The poems in this book originated as songs which were passe from one generation to the next. For joung readers.

KRUTCH, J. W.: THE VOICE OF THE DESERT, $\$ 2.50$, paper. This book explores the rich, intriguing, unexpected variety of iffe in America's southwest.

LIFE, editors of, and BARNETT, L.: THE WORLD WE LIVE IN, $\$ 2.00$, paper. 150 supe 1llus. in colour. A fascinating account of our world told in "Life" Mag.

MAC FARLAN, A. A.: HUNTING SECRETS OF THE INDIANS, \$8.25. Indian technique for today's outdoorsmen. The Indian's skill in getting close to wildife is described as an ald to those of us who stalk with camera.

MILES, C.: INDIAN AND ESKTMO ARTIFACTS OF NORTH AMERIC,$\$ 7.95$ (Orig. $\$ 30.00$ ), $8 \frac{3}{4} \times 1 i \frac{1}{4}$. Over 2000 examples in this pictorial guide, including 7 color pis covering all of the major kinds of native-made artifacts - tools, weapons, pottery, basketry, boats, regalia, etc. - with lore and useage.

MINTON, S. \& M.: VENONOUS REPTILES, \$3.70. A herpetologist and his wife combir scientific reporting with personal experiences to give a comprehensive and intriguing view of venomous reptiles. 
MITCHELL, R. T. \& Z TM, H. S.: BUTTERFLIES AND MOTHS, \$1.50, paper. A "Golden Nature" Guide. Describes the more common American species.

MURPHY, ROBERT: WILD SANCTUARIES: Our National Wildilfe Refuges - a Heritage Restored, 15.95 (was $\$ 26.95 !)$ A heartening look at wildlife sanctuaries in the U. S. Illus. with 48 colour photos \& $227 \mathrm{~b} . w ., 32$ maps. $8 \frac{3}{4} \times 11 \frac{1}{4}$.

MUSSELMAN, $\nabla$. W.: LEARNING ABOUT NATURE THROUGH PETS, $\$ 4.95$. For children and parents who know nothing about animals, here are the facts about choosing, identifying, handling, feeding, and housing animals, birds, and fish.

NICOL, C. W.: FROM THE ROOF OF AFRICA, 10.75 . Nicol is the tough young Nelsh game warden who was commissioned by Faile selassie to establish simien National Park in the backlands of Ethiopia. For three years he worked in a primeval landscape where the ecological balance remeins undisturbed.

PATTON, B. \& ROBINSON, B.: THE CANADIAN ROCKIES TRAIL GUIDE - $A$ Hiker's Nanual. \$3.95. There is a growing interest in backpacking and wilderness trekking. Hach mejor trail is given a 2-page display will detailed data, and over 100 secondary trails are outlined with added detalls. 208 pp. illus. PEARL, R. M.: HOW TO KNOW THE MINERALS AND ROCKS, paper, \$2.25. A complete guide to aid you in finding and classifying more than 125 rocks \& minerals.

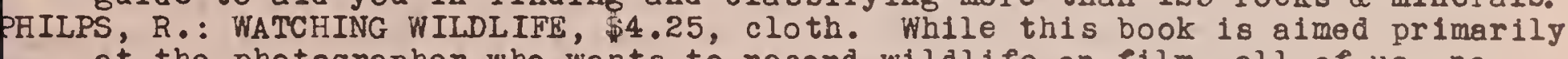
at the photographer who wants to record wildife on film, all of us, no matter what our background or interest, can take advantage of the tips.

DUR AMAZING NORID OF NATURE: Its Marvels and Mysteries, by the eiditors of Reader's Digest and 70 eminent naturalists. Cloth, 12.50 . Fastastic creatures and incredible wonders, delightful, awe-inspiring, educational.

KEID, G. K. \& ZIM, H. S.: POND LIFE, paper, \$1.50. A "Golden Nature" guide to common plants and animals of American ponds and lakes. A pond or lake offers opportunities for exciting discoveries and this guide will help you

HODES, F.H.T., ZIM, H.S., SHAFFER, P.R.: FOSSILS, paper, \$1.50. This "Golden Nature" Guide is indispensable to the probing field naturalist, no matter what his interest as you never know when you will come across a fossil.

OBINSON, D. H.: A CAMPER'S AND HIKER'S GUIDE TO THE BLUE RIDGE PARKWAY, \$2.50. A complete guide to camping and hiking in the Blue Ridge Parkway in North Carolina and Virginia, the Necca of so many general amateur naturalists.

OOD, Ronald: ANIMALS NOBODY LOVES, $\$ 7.25,160 \mathrm{pp}$., 11lus. In defense of a dozen creatures that man has harassed, hunted, hated and murdered - pigs, rats, snakes, fleas, bats, spiders, vultures, eels, coyotes, wolves.

CHERIIAN, K.: TWO ISLANDS: GRAND MANAN \& SANIBEL, \$9.00. A celebration of two islands, one off the Bay of rundy and one off the tip of Florida. Here are lonely wild spots still largely unspoiled and unexploited.

ITON, «5. T.: BIOGRAPHY OF A GRIZZLY, \$2.75, hard. The classic story of Wahb the grizzly bear who ruled his vast dominion in the western mountains.

TOUTENBURGH, J.: UICTIONARY OF THE AMERICAN INDIAN, $\$ 2.75$, cloth. $459 \mathrm{pp}$. An up-to-date source book for the student, researcher or individual who wants a fuller understanding of the glossary of indian-oriented terms.

TMONS, R. D.: MANY TRAILS, \$1.75, paper. Bob Symons' first book, a fascinating account of a cowboy's life on the early range of the west.

INIS, E.: CHIPMUNKS ON THE DOORSTEP, $\$ 5.95$, il lus, 'ine author practically interviewed the chipmunks who allowed him to live on his property. The book is marvellous personal essay that rivals Thoreau.

INNISSON, A. C.: COLORFUL MINERAL IDENTIFIER, 4.50 . Each of 120 minerals is not only pictured in full colour but is completely described. $256 \mathrm{pp}$.

ITTE, G.: THE NATURAL HISTORY OF SELBORNE, $\$ 4.00$, cloth. First pub. 1788,150 or more editions printed, evidence of the affection and interest this classical work still commands. This edition was edited by the late James Fisher, ornithologist, who gives a close and careful commentary on the tert ODIN, A.: : HOME IS THE DESERT, $2.95,255 \mathrm{pp}$. The wife of the director of the Arizona-Sonora Desert Museum and her sensitive and beautiful book tells of the intimate daily iffe of a family thoroughly en joying the wilderness. 


\section{$-12-$ \\ CONSERVATION - ECOLOGY - POLLUTION}

ALIEN, S. W., \& LEONARD, J. W.: CONSERVING NATURAL RESOURCES, \$11.30. A revis ion of the well-known "Conserving Natural Resources: Principles and

Practices in a Democracy", and now an even better teaching textbook.

BRINKHURST, R. O. \& CHANT, D. A.: THIS GOOD, GOOD EARTH: OUR FIGHT FOR SLRVIVA $\$ 8.50$. The authors detail the mass 1 ce attack we must make, recommending startling and provocative ways to carry it out.

CARAS, R.: DEATH AS A WAY OF LIFE, 6.75 . Caras demonstrates that hunting is more than simply sport or economic necessity.

COMMONER, B: "THE CIOSING CIRCLE: TECHNOLOGY, NATURE AND MAN" \$8.25. The most imperative, most radical, most creative book yet written on the impending environmental disaster. It's an urgent call for a social revolution.

DASMANN, R.: AN ENVIRONMENT FIT FOR PEOPIE, 35\&, paper. The famous conservationist describes the mess we're in, and suggests that our greatest ne日d is for control of our technology so that it may be used to our benefit.

EDINBURGH, H.R.H. THE PRINCE PHILIP, DUKE OF, \& FISHER; J.: WIIDLIFE CRISIS, $\$ 18.75$. The authors describe the need for organized conservation, and include a 32-page compendium of man's devastating impact on nature.

FISHER, J.: WHAT YOU CAN DO ABOUT POLLUTION NOW, \$2.95. Few average citizens know enough about the magnitude of the poliution problem to help much. In this book Fisher describes what can be done about it by the man in street

FRASER, D.: THE PEOPLE PROBLEM, \$8.75. A vigorous discussion written in layman's language. An answer to the otherwise inescapable disaster.

GRAHAM, F.: SINCE SILENT SPRING, 95\% paper. A ringing vindication of Carson's warnings in her controversial SILENT SPRING. This is a tocsin volume the should seal the doom of chemical pesticides before they kill us all off:

GROSSMAN, S.: UNDERSTANDING ECOLOGY, \$4.95. This thought-provoking book is a superb introduction to the entire study of natural life in $N$. America.

GUGGISBERG, C.A.W.: MAN AND WIIDLIFE, \$16.95. Profusely illustrated, this work traces man's long relationship with animals. Includes a unique guide to the world's national parks and wildilfe sanctuaries.

HANSON, H. C.: DICTIONARY OF ECOLOGY, $\$ 3.25$, cloth, $382 \mathrm{pp.} \mathrm{Includes} \mathrm{not} \mathrm{only}$ ecological terms but also those that have been adopted from related field

WILD IIFE CONSERVATION, \$4.95, $160 \mathrm{pp}$. The urgent need for wildl1fe conservation is at lest receiving worldwide recognition. A far-ranging book, stimulating and informative, and of value to us with our own future in vie

\section{WESTERN CANADIANA}

COULTER, J.: THE TRIAL OF LOUIS RIEL, $\$ 2.00$ paper, 72 pp. The script, based on the actual court records, of the famous Regina play.

FRANKLIN, J.: NARRATIVE OF A SEUOND EXPEDITION TO THE SHORES OF THE POIAR SEA: In the years 1825, 1826 and 1827, including an account of the progress af a detachment to the east, by John Richardson. New intro. by Dr.L.H.Neatb 512 pp., $7 \times 10 \frac{1}{4}, 31$ illus., 5 maps, fine cloth binding, boxed 25.00 .

MAC INTYRE, D. E.: PRA IRIE STOREKEEPER, \$4.95. Macintyre opened Tuxford's first store in 1906. A funny, informative, warm, kind book.

MACKENZIE, ALFXANDER: VOYAGES FROM MONTREÁ, on the River St. Lawrence, throug the Continent of North Amerlca to the Frozen and Pacific Oceans, I789 and 1793, \$20.00. A gorgeous reproduction of the 1801 first edition, with me

MACGREGOR, J.G.: THE LAND OF TWELVE-FOOT DAVIS, pe per $\$ 3.25$, cloth \$5.00. Provides the significant facts about the early beginnings of the Peace River country.Bich in vivid descriptions of things and people. $395 \mathrm{pp}$.

SYNONS, R. D.: STILI THE WIND BLOWS. An historical novel with its roots in t] involvement of the Cree Indians in the Riel Rebellion of 1885 . Bob Symor has given us a truly Canadian story for the rorld. (Price not known.)

SWAINSON, D.: HISTORICAL ESSAYS ON THE PRAIRIE PROVINCES, \$3.75. These 19 essays span the whole history of the rest and study in detall major aspe of prairie life - politics, economics and society. 
mary glands for excretion in the fatty acid fraction of the milk of nursing females occurs in most mammals, including cows (Henderson, 1965), dogs (Woodward et al, 1945), rats (Radom-. ski and Davidow, 1953), and human beings (Quinby et al, 1965). Suckling young are therefore directly exposed to potentially serious biocide levels early in their life. Further, at least two chlorinated hydrocarbons (DDT and dieldrin) are known to move across the placenta in dogs (Finnegan et al, 1949) and mice (Backstrom et al, 1965) and to accumulate subsequently in the adipose tissue, liver, reproductive organs and brain of the embryos.

The demonstration of excretion in milk and of transfer to unborn embryos has serious implications with regard to the reproductive biology of mammals exposed to even low residue levels in the field. Although the magnitude and expression of effect depends on several variables including the biocide itself, the species of mammal and the duration of exposure, laboratory studies suggest that aldrin, dieldrin, DDT and endrin all have essentially similar adverse effects on the reproductive biology of small mammals (Bernard and Gaertner, 1964; Morris, 1968; Treon and Cleveland, 1955). These effects include an increase in adult mortality and in either pre-natal or post-natal mortality of young, a decrease in the size and frequency of litters and a decrease in the number of pregnancies.

Residue contamination is not, of course, restricted to small mammals. However, the biological significance of residue levels found in large mammals is generally not so well known as it is in small mammals. The fat component in tissues of large mammal game species including wild mule deer, white-tailed deer, pronghorns and elk in Montana (Pillmore and Finley, 1963) and South Dakota (Greenwood et al, 1967) contains dangerously high residues of DDT (maximum, $42 \mathrm{ppm}$ ) and dieldrin (maximum, $4 \mathrm{ppm}$ ). It is noted here that the tolerance level set by the United States Food and Drug Administration (USFDA) for residue contamination in domestic livestock for human consumption is $7 \mathrm{ppm}$ (DDT) and zero ppm (dieldrin). Parenthetically, by these standards citizens of the United States are unfit for human consumption. They carry, on average, a body burden of $13 \mathrm{ppm}$ DDT and $0.15 \mathrm{ppm}$ dieldrin (Hayes, 1964).

Trophic concentration (see Hunt, 1966) significantly increases the biocide load of species of predators. The effect becomes more serious if the vertebrate prey develops resistance to a biocide. Individuals from mouse populations with a history of exposure to biocides have developed resistance to DDT in the laboratory (Ozburn and Morrison, 1967) and to endrin in the field (Webb and Horsfall, 1967). The presence of resistant types in a population produces a biological product which is "poison bait" for any consumer, including man. Residents of Mississippi consume fresh-water green sunfish whose edible tissues contain up tc $27 \mathrm{ppm}$ endrin (Ferguson, 1967). The USFDA tolerance level for endrin in human food is zero ppm.

In addition to the stated specific instances of the effects of biocides on mammals, the major kinds of effects produced on populations of wild mammals are summarized in Figure 1. These include direct lethal and sublethal toxic effects, and indirect nontoxic effects. Such effects need not be restricted to local populations living in or near a chemical spray area, but can spread in time and space to affect populations far removed from the site of application.

The figure is generalized in that it could apply, if modified slightly, to most species of vertebrate. For example, McEwan \& Brown (1966) working with Sharp-tailed Grouse demonstrated that a single sublethal dose of dieldrin caused changes in social hierarchy among males, and increased vulnerability to predators. Further, as different species of insects react differently to the same insecticide (Pimental, 1961), the pathways described need not apply equally to all vertebrate species. 


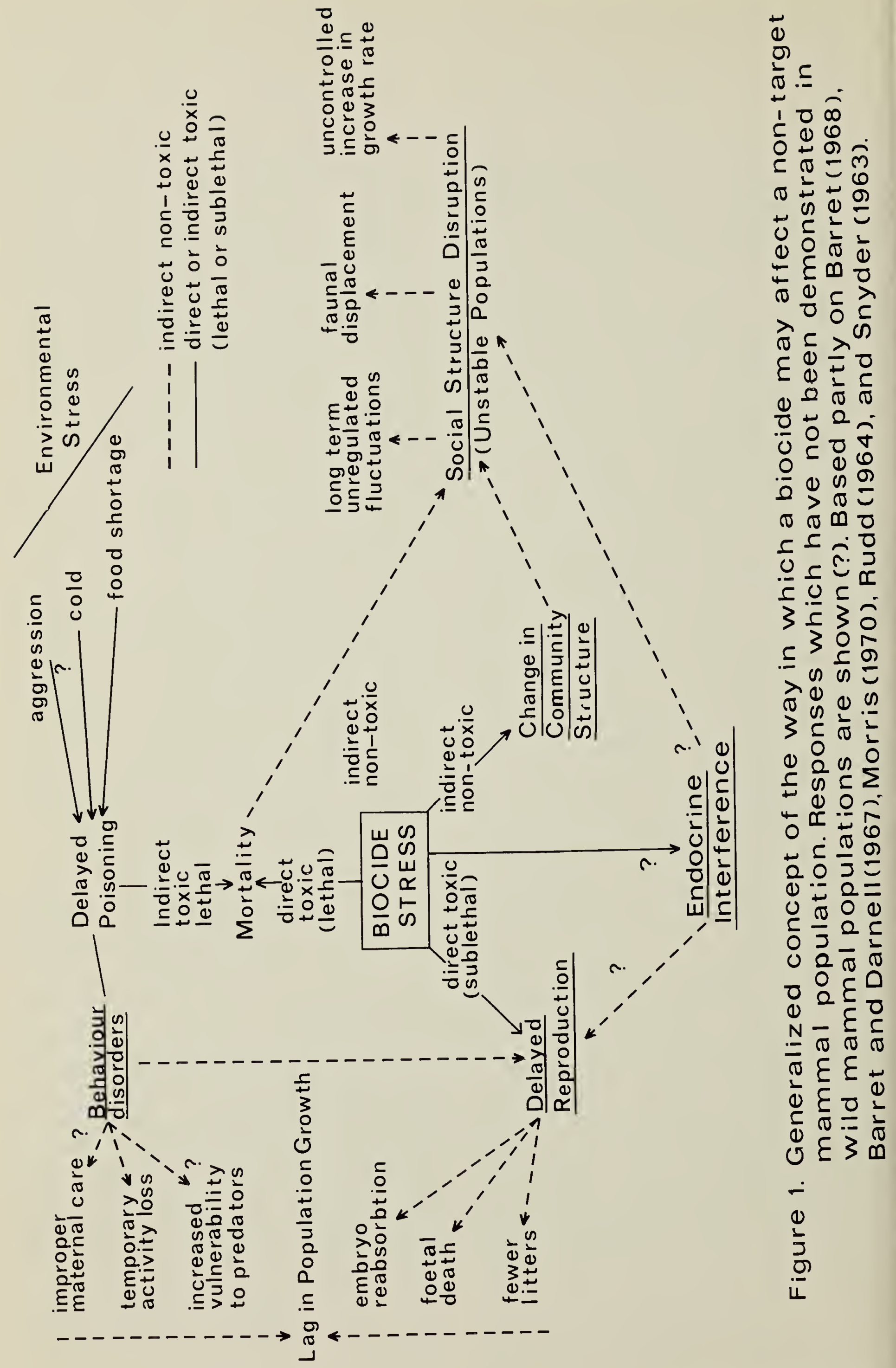




\section{Conclusions}

The government of Canada is to be commended for recent DDT control legislation. By this step, Canada joins a growing list of political regions, local and national, which have declared controls on the sale and use of DDT (see MacMullen, 1968; Mosquin, 1969). Twenty-five years of intensive research has established the basis for such legislation by demonstrating that DDT is a significant and dangerous environmental pollutant. The physiological and ecological actions of aldrin, dieldrin, endrin, heptachlor and toxaphene are actually or potentially more serious than those of DDT. It should be clear that the physiology of individual human beings and the ecology of human populations is sufficiently similar to those of other mammals that similar responses to chlorinated hydrocarbon biocides might be expected.

The weight of evidence is overwhelmingly against the continued practice of uncontrolled use of chlorinated hydrocarbon chemicals. Chant (1969) has already urged the government of Canada to "impose an absolute ban on the further manufacture, sale or use of DDT, aldrin, dieldrin, and heptachlor." A large portion of his resolution dealt with adverse effects on the health of man. I submit that the government of Canada need not further reserve judgment in the matter of meaningful legislative controls on all chlorinated hydrocarbon chemicals. The current practice of requiring a demonstration of actual or potential lethality to humans before taking action is unnecessary and should be abandoned.

The Minister of Health and Welfare of Canada and the Minister of Agriculture of Canada should be urged in the strongest possible terms to give thoughtful consideration to the following recommendations :

1) that the government of Canada recognize the similarities in the physiological and ecological actions of all chlorinated hydrocarbon chemicals and extend the existing DDT legislation to include aldrin, dieldrin, endrin, heptachlor and toxaphene.
2) that the government of Canada encourage the use of alternate chemicals which are less residual than the chlorinated hydrocarbons. In order that such a step be effective, the manufacture, sale and application procedures should be under strict government control so that purchase and use by private individuals will be better regulated.

3) that the government of Canada develop a program of cash incentives to encourage farmers to a) leave natural areas of grassland and woodland adjacent to food crop fields, and b) plant shelter-belts of native vegetation within and adjacent to food crop fields. It has been clearly demonstrated that over-simplification of an ecosystem by the removal of all natural vegetation (monoculture) encourages insect pest outbreaks (Cole, 1964; 1966; Egler, 1966). With this practice, ecological diversity is disrupted and instability is encouraged so that chemicals are not as effective as claimed. In fact, insect numbers may actually reach higher densities following biocide treatment (reviewed by Ripper, 1956). The reasons are related to development of resistance (Brown, 1958), to removal of competitor insect species (Pimental, 1961) or to reduction of predaceous insect species (Pickett, 1961). More reliance should be placed on natural controls or on the selective use of chemicals.

4) that the government of Canada recognize local or national legislative controls to be insufficient protection for a global environment already seriously threatened by a dangerously high load of chlorinated hydrocarbon and other insecticides (Wurster, 1969; see also, Erhlich, 1969). Presentation of a resolution to the United Nations encouraging a ban on all uncontrolled sale or use of the chlorinated hydrocarbon biocides is suggested. The expected defensive argument of "more insecticides to feed more people" is considered invalid (Paddock and Paddock, 1967).

\section{LITERATURE CITED}

Abbott, D. C., R. B. Harrison, J. O'G. Tatton, and J. Thomson. 1965. Organochlorine pesticides in the atmospheric environment. Nature, $208: 1317-1318$. 
Backstrom, J., E. Hansson, and S. Ullberg. 1965. Distribution of $\mathrm{C}^{\mathbf{1 4}}-\mathrm{DDT}$ and $\mathrm{C}^{\mathbf{1 4}}$ -dieldrin in pregnant mice determined by whole-body autoradiography. Toxicol. and Appl. Pharmacol., $7: 90-96$.

Barrett, G. W. 1968. The effects of an acute insecticide stress on a semi-enclosed grassland ecosystem. Ecology, $49: 1019-1035$.

Barrett, G. W., and R. M. Darnell. 1967. Effects of dimethoate on small mammal populations. Amer. Midl. Natur., $77: 164-175$.

Bernard, R. F., and R. A. Gaertner. 1964. Some effects of DDT on reproduction in mice. J. Mamm., $45: 272-276$.

Brown, A. W. A. 1958. The spread of insecticide resistance in pest species. Advances Pest Control Res., $2: 351-414$.

Carson, R. 1962. Silent spring. HoughtonMifflin Co., Boston. 368 pp.

Chant, D. A. 1969. A petition requesting a ban on DDT and related pesticides. Submitted to Minister of Agriculture and Minister of Nat. Health and Welfare, 25 September, 1969. mimeo, 5pp.

Cole, L. C. 1964. Pesticides: a hazard to nature's equilibrium. Amer. J. Public Health, 54 (Suppl) : 24-31.

Cole, L. C. 1966. The complexity of pest control in the environment. In: Sci. Aspects of Pest Control, NAS-NRC Publ. $1402: 13-25$.

Conney, A. H. 1967. Pharmacological implications of microsomal enzyme induction. Pharmacol. Rev. 19:317-366.

Dale, W. E., T. B. Gaines, and W. J. Hayes, Jr. 1962. Storage and excretion of DDT in starved rats. Toxicol Appl. Pharmacol. $4: 89-106$

Egler, F. E. 1966. Pointed perspectives: pesticides in our ecosystem. Ecology, 47:1077. 1084

Ehrlich, P. 1969. Eco-catastrophe: Ramparts, $8: 24-28$.

Ferguson, D. E. 1967. The ecological consequences of pesticide resistance in fishes. Trans. North Amer. Wildl. Conf., $32: 103-107$.

Finnegan, J. K., H. B. Haag and P. S. Larson. 1949. Tissue distribution and elimination of DDD and DDT following oral administration to dogs and rats. Proc. Soc. Exp. Biol. and Med., $72: 357-360$.

Greenwood, R. J., Y. A. Greichus, and E. J. Hugghins. 1967. Insecticide residues in big game mammals of South Dakota. J. Wildl. Mgmt., $31: 288-292$.

Hayes, W. J., Jr. 1964. Epidemiology of pesticides. In: Proc. of a course on the occupational health aspects of pesticides. (E. Link and R. J. Whitaker, Eds.) Univ. of Okla., Norman. pp. 109-130.

Hayes, W. J., Jr. 1965. Review of the metabolism of chlorinated hydrocarbon insecticides especially in mammals. Ann. Rev. Pharmocol., 5 :27-52.

Henderson, J. L. 1965. Insecticide residues in milk and dairy products. Residue Reviews, $8: 74-115$.

Hickey, J. J., and D. W. Anderson. 1968. Chlorinated hydrocarbons and eggshell changes in raptorial and fish-eating birds. Science $162: 271-273$

Hunt, E. G. 1966. Biological magnification of pesticides. In : Sci. Aspects of Pest Control. NAS-NRC Pubi. 1402 :251-262.

Jukes, T. H. 1963. People and pesticides. Amer. Sci., $51: 355-361$.

MacMullen, R. A. 1968. The case against hard pesticides. Mich. Conserv., Jan-Feb: 1-6.

McEwan, L. C., and R. L. Brown. 1966. Acute toxicity of dieldrin and malathion to wild sharp-tailed grouse. J. Wildl. Mgmt., 30 : 604-611.

Morris, R. D. 1968. The effects of endrin feeding on survival and reproduction in the deer mouse, Peromyscus maniculatus. Can. J. Zool., 46 :951-958.

Morris, R. D. 1970. The effects of endrin on Microtus and Peromyscus. I. Unenclosed field populations. Can. J. Zool., 48:695-708

Mosquin, T. 1969. Governments move to ban chlorinated hydrocarbons. Can. Field-Nat., $83: 189-190$

O'Brien, R. D. 1967. Insecticides, action and metabolism. Acad. Press, N.Y. 332 pp.

Ozburn, G. W., and F. O. Morrison. 1962 Development of a DDT-tolerant strain of laboratory mice. Nature, $196: 1009-1010$.

Paddock, W., and P. Paddock. 1967. Famine1975! Little-Brown, Boston.

Peakall, D. B. 1967. Pesticide-induced enzyme breakdown of steroids in birds. Nature, $216: 505-506$

Pickett, A. D. 1961. The ecological consequences of chemical control practices on arthropod populations in apple orchards in Nova Scotia, Canada. Proc. 8th Tech. Meeting, Intern. Union for Conserv. of Nature and Nat. Res., Warsaw (1960): 19-24.

Pillmore, R. E., and R. B. Finley, Jr. 1963. Residues in game animals resulting from forest and range insecticide applications. Trans. North Amer. Wildl. Conf., 28:410422.

Pimental, D. 1961. An ecological approach to the insecticide problem. J. Econ. Ent., 54: 108-114.

Quinby, G. E., J. F. Armstrong and W. F. Durham. 1965. DDT in human milk. Nature, $207: 726-728$.

Radomski, J. L., and B. Davidow. 1953. The metabolite of heptachlor: its estimation, storage and toxicity. J. Pharmacol. Exptl. Therapeut., $107: 266-272$.

Ratcliffe, D. A. 1967. Decrease in eggshell weight in certain birds of prey. Nature $215: 208-210$.

Ripper, W. E. 1956. Effect of pesticides on balance of arthropod populations. Ann. Rev. Entomol., $1: 403-438$.

Risebrough, R. W., R. J. Huggett, J. J. Griffin, and E. D. Goldberg. 1968. Pesticides: transatlantic movements in the northeast trades. Science, $159: 1233-1236$.

Rudd, R. L. 1964. Pesticides and the living landscape. Univ. of Wisc. Press, Madison. $320 \mathrm{pp}$.

Sladen, W. J. L., C. M. Menzie, and W. L. Reichel. 1966. DDT residues in Adelie penguins and a crab-eater seal from Antarctica: ecological implications. Nature, $210: 670-673$. Snyder, B. D. 1963. The effects of endrin on vole (Microtus pennsylvanicus) reproduction in bluegrass meadows. Ph.D. Thesis, Ohio State Univ., $119 \mathrm{pp}$.

Treon, J. F., and F. P. Cleveland. 1955. Toxicity of certain chlorinated hydrocarbon insecticides to laboratory animals with special reference to aldrin and dieldrin. $J$ Agri. Food Chem., 3:402-408.

Webb, R. E., and F. Horsfall, Jr. 1967. Endrin resistance in the pine mouse. Science, 156: 1762.

Woodward, G., R. R. Ofner, and C. M. Montgomery. 1945. Accumulation of DDT in the body fat and its appearance in the milk of dogs. Science, $102: 177-178$

Wurster, C. F. 1969. Chlorinated hydrocarbon insecticides in the world ecosystem. Biol. Conservation, $1: 123-129$. 